\title{
REKONSTRUKSI TEORI CONSUMER EQUILIBRIUM PERSPEKTIF EKONOMI ISLAM
}

Mochlasin

\begin{abstract}
Abstrak
Keseimbangan menjadi prinsip penting dalam ajaran Islam yang kemudian dapat dikembangkan menjadi dasar rancang bangun ekonomi Islam. Untuk menjelaskan konsep keseimbangan konsumen yang bersumber dalam al-Qur'an, tulisan ini akan menggunakan pendekatan integral (unitied approuch) yang digagas oleh Muhammad Anas Zarqa terutama dari tulisannya, Islamiation of Economics: The Concept and Metodology. Metode ini dibangun di atas asumsi, bahwa sebagian teori ekonomi dan wahyu dapat saling memperkuat dan mendukung. Kata qawam yang terdapat dalam surat al-Furqan ayat 67 menjadi kata kunci dalam tulisan ini untuk membangun teori tentang consumer equilibrium (keseimbangan konsumen) dalam ekonomi Islam sebagaimana telah jamak dikenal dalam ekonomi konvensional. Konsep consumer equilibrium dalam ekonomi konvensional yang digambarkan dengan budget line dan kurva indeferen, dapat digunakan untuk menggambarkan maksud surat al-Furqan ayat 67. Namun demikian, karena terdapat prinsipprinsip dasar yang berbeda seperti konsep tentang kebutuhan dan pertimbangan maslahah, maka budget line dan kurva indeferen tidak secara otomatis dapat menjelaskan maksud suatu ayat yang mengandung muatan ekonomi.
\end{abstract}

Keyword: Consumer equilibrium, consumer behavior, ekonomi Islam.

\section{Pendahuluan}

Dalam kehidupan keseharian, seseorang senantiasa dihadapkan pada pilihan penggunaan uang untuk membeli barang atau jasa yang dibutuhkan. Dalam menentukan pilihan seseorang dituntut untuk menyeimbangkan antara kebutuhan, preferensi dan ketersediaan sumber daya. Keputusan seseorang untuk memilih 
alokasi sumber daya inilah yang melahirkan fungsi permintaan. Setiap saat seseorang selalu dituntut mengambil sejumlah keputusan bagaimana mengalokasikan sumber daya untuk memenuhi kebutuhan. Kajian tentang bagaimana seseorang menentukan pilihan-pilihannya dalam kajian eknomi disebut dengan perilaku konsumen (consumer behavior).

Teori consumer behavior dalam kajian ekonomi, menyatakan bahwa konsumen senantiasa menginginkan tingkat kepuasan maksimum yang digambarkan dengan kurva indeferen. Dalam ekonomi konvensional, konsumen diasumsikan selalu bertujuan untuk memperoleh kepuasan dalam kegiatan konsumsinya. (utility maximization assumption). Kepuasan itu hanya diabatasi oleh budget line (garis anggaran), karena dalam ilmu eknomi konvensional motif ekonomi didasarkan pada keinginan (want). Pertemuan antara budget line (garis anggaran) dengan kurva indeferen (keinginan) itulah yang menghasilkan kepuasan maksimal dan dikatakan sebagai titik equilibrium (Reksoprayitno, 2007: 180).

Abdurrazaq Nawfal pernah menulis buku yang menakjubkan yang berjudul al-I'jaz al-Adabiy li al-Qur'an al-Karim, salah satu bahasannya berisi tentang empat bentuk keseimbangan dan keserasian jumlah kata di dalam alQur'an. Di antaranya adalah keseimbangan antara jumlah bilangan kata dengan antonimnya. Sebagai contoh, kata al-hayah (hidup) dan al-mawt (mati) samasama berjumlah 145 kali. Kata al-naf' (manfaat) dan al-madharah sama-sama berjumlah 50. Selanjutnya kata al-har (panas) dan al-bard (dingin) disebut sebanyak empat kali. Demikian juga kata as-shalihat (kebaikan) dan as-sayyiat (keburukan) disebut masing-masing 167 kali. Kata al-kufr (kafir) dan al-iman (bentuk indifinite) disebut sebanyak 8 kali (Shihab, 1992: 29-30).

Keserasian jumlah kata di atas dalam tingkat tertentu menjadi bukti keotentikan al-Qur'an. Namun lebih dari itu, keserasian kata-kata yang digunakan al-Qur'an, sebenarnya memberikan suatu pelajaran yang cukup berharga bagi manusia bahwa hidup ini memerlukan keseimbangan. Keseimbangan pada hakikatnya adalah bagian dari sunnatullah. Jika keseimbangan tidak terjaga, maka yang akan terjadi adalah kehancuran alam dan umat manusia itu sendiri. Mengacu dengan keseluruhan konsep dalam al-Qur'an, terdapat tiga keseimbangan (eqeliubirium) yang harus dilakukan manusia, yaitu: 1) keseimbangan antara kehidupan dunia dan akhirat; 2) keseimbangan antara kebutuhan jasmani dan rohani; dan 3)keseimbangan kepentingan individual dan sosial. 
Sebagaimana disebutkan di atas, keseimbangan menjadi prinsip penting dalam ajaran Islam yang kemudian menjadi aras pengembangan ekonomi Islam. Untuk menjelaskan konsep keseimbangan konsumen yang bersumber dalam alQur'an, tulisan ini akan menggunakan pendekatan integral (unitied approuch) yang digagas oleh Muhammad Anas Zarqa terutama dari tulisannya Islamization of Economics: The Concept and Metodology (2003).

\section{Consumen Behavior dalam Ekonomi Konvensional dan Islam}

Sebelum membicrakan tentang consumer equilibrium, tentunya kajian harus dimulai dari pengertian Consumen Behavior. Della Bitta (1993) mendefinisikan perilaku konsumen adalah: as the decision process and physical activity individuals engage in when evaluating, acquiring, using, or disposing of goods and services (perilaku konsumen sebagai suatu proses pengambilan keputusan dan aktivitas individu secara fisik yang melibatkan dalam mengevaluasi, memperoleh, menggunakan atau dapat mempergunakan barang-barang dan jasa). Shiffman dan Kanuk (2000) mendfinisikan: Consumer behavior can be defined as the behavior that customer display in searching for, purchasing, using, evaluating, and disposing of products, services, and ideas they expect will satisfy they need. Seara lebih operasional, John C. Mowen dan Michael Minor (2001) mendifinisikan perilaku konsumen sebagai suatu studi tentang unit pembelian (buying units) dan proses pertukaran yang melibatkan perolehan, konsumsi, dan pembuangan barang, jasa, pengalaman, serta ide-ide.

Dari beberapa definisi di atas dapat disimpulkan, teori perilaku konsumen adalah upaya menerangkan perilaku konsumen dalam membelanjakan pendapatannya untuk memperoleh alat-alat pemuas kebutuhan, yang dapat berupa barang-barang konsumsi atau jasa-jasa konsumsi. Dengan demikian dapat ditegaskan, bahwa teori konsumen merupakan dasar teoritik kurva permintaan akan barang-barang dan jasa konsumsi (Reksoprayitno, 2007: 143). Dalam ekonomi konvensional, konsumen diasumsikan selalu bertujuan untuk memperoleh kepuasan (utility/satisdaction) dalam kegiatan konsumsinya. Utility secara etimologi, berarti berguna (usefulness), membantu (helpfulness) dan menguntungkan (advantage) (UII dan BI, 2007: 127). 
Menurut Boediono, pengertian yang paling sederhana tentang perilaku konsumen didapati dari hukum permintaan. Menurut hukum itu, jika harga sesuatu barang naik, maka ceteris paribus jumlah yang diminta konsumen akan barang tersebut turun. Sebaliknaya, bila harga barang itu turun ceteris paribus, berarti semua faktor lain yang mempengaruhi jmlah yangdiminta ndianggap tidak berubah (Boediono, 2002: 17-18). Menurut Kahf, Teori perilaku konsumen yang sekarang berkembang dalam ilmu ekonomi Barat setelah munculnya kapitalisme yang bertumpu pada filsafat rasionalisme ekonomik dan utilitarianisme (Kahf, 1995: 16). Teori perilaku konsumen berdasarkan sistem kapitalis Terdapat dua pendekatan berdasarkan hukum permintaan. Pertama, pendekatan marginal utility yang bertitikatolak pada satuan lainnya yang besifat kardinal. Kedua, pendekatan indefference curve yaitu tidak memerlukan adanya anggapan bahwa kepuasan konsumen bisa diukur (bersifat ordinal) (Boediono, 2002: 17-18). Keputusan seseorang untuk memilih alokasi sumber daya inilah yang akirnya melahirkan fungsi permintaan (demand side).

Dalam ekonomi konvensional, terdapat dua kriteria dalam melihat perilaku konsumen: (1) tujuan konsumen adalah mencapai kepuasan tertinggi; (2) batasan konsumen hanyalah kemampuan anggaran. Dalam kenyataan di pasar transaksi, konsumen selalu dihadapkan pada pilihan barang, harga dan lain-lain. Pilihan-pilihan tersebut dinamakan faktor yang mepengaruhi konsumen dalam membelanjakan income. Teori perilaku konsumen dibangun atas dasar asumsi rasionalitas, yaitu asumsi yang menyatakan bahwa konsumen senantiasa berusaha menggunakan pendapatannya yang jumlahnya terbatas untuk mendapatkan kombinasi barang-barang dan jasa-jasa yang diperkirakan akan mendatangkan kepuasan maksimum. Di samping itu, teori perilaku konsumen juga didasarkan pada asumsi perfect knowledge (pengetahuan sempurna). Kesempurnaan pengetahuan itu meliputi jenis barang dan konsumsi, harga masing-masing barang dan jasa, besarnya pendapatan serta cita rasa (Reksoprayitno, 2007: 144).

Untuk memahami peran sikap dalam perilaku konsumen, terlebih dahulu harus memahami bagaimana sikap dikembangkan dan bagaimana peran yang dimainkan. Sikap dikembangkan sepanjang waktu melalui proses pembelajaran yang dipengaruhi oleh pengaruh keluarga, kawan sebudaya, informasi, pengalaman dan kepribadian. Perhatian utama para pemasar adalah bagaimana kepercayaan mempengaruhi sikap terhadap merek dan bagaimana sikap terhadap 
merek mempengaruhi perilaku. Hubungan antara ketiga hal itu sangat penting bagi pemasar karena akan menentukan strategi pemasaran yang berhasil. Jika iklan yang ditampilkan mampu menciptakan kepercayaan positif terhadap merek, konsumen akan lebih mungkin untuk mempunyai sikap positif dan membeli produk itu.

Kepuasan atas penggunaan produk akan memperkuat sikap dan mempertinggi probabilitas pembelian kembali. Selanjutnya untuk memudahkan alur penelitian, maka penelitian ini menggunakan pendekatan teori pemasaran yang dikembangkan oleh Kotler. Menurut Kotler (1997) customer characteristics) adalah sifat-sifat masyarakat yang mempengaruhi proses keputusan untuk membeli produk atau jasa. Karakteristik masyarakat, bersifat kultural, sosial, personal, dan psikologis (Kotler 1997, 172). Model ini menurut Kotler dapat digambarkan berikut ini:

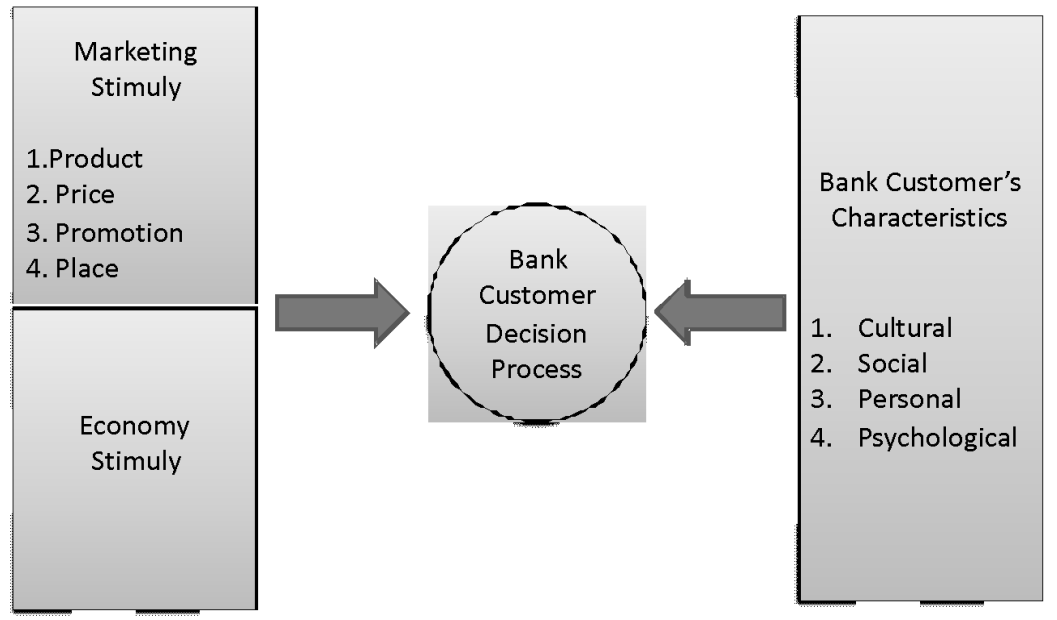

Dalam framework ekonomi konvensional, masalah ekonomi muncul diasumsikan karena kelangkaan sumber daya, oleh karennya solusi yang ditawarkannya aalah menghilangkan kelangkaan sumber daya.Tentunya solusi ini tidak akan menyelesaikan masalah, karena ketidakmampuan yang melekat pada sumber daya 
materi untuk memenuhi semua yang diinginkan (want) manusia sebagaimana telah dijelaskan dalam beberaya ayat al-Qur'an. Kepuasan (satisfaction) yang diinginkan manusia sebenarnya hanyalah asumsi teoritik untuk menyelesaikan problem ekonomi. Sedangkan dalam framework ekonomi Islam, aktivitas ekonomi dilakukan dalam rangka menjaga kesejahteraan (maslahah). Kegiatan ekonomi yang mengkaitkan maslahah, dilakukan sebagai kewajiban keagamaan untuk mendapatkan kebaikan tidak hanya di dunia ini tapi juga di akherat. Semua aktivitas yang yang memiliki maslahah bagi umat manusia disebut kebutuhan (need), dan kebutuhan ini memang harus dipenuhi (Khan, 1995: 37).

Fokus utama dalam ekonomi kapitalis adalah efisiensi, Mungkin maksud Anda adalah: this concern emerges directly from its definition of economic problem. ....if our wants are virtually unlimited and resources are scarce, we cannot conKetikkan teks atau alamat situs web atau kekhawatiran ini sebenarnya muncul langsung dari definisi masalah ekonomi itu sendiri. Konsep efisien dalam ekonomi kapitalis adalah untuk memaksimalkan kepuasan dengan sumberdaya yang tersedia. Adapun dalam Islam, efisiensi dimaknai sebagai memaksimalkan pemenuhan kebutuhan (maslahah) dengan sumber daya yang tersedia. Permasalahan kemudian muncul, apabila kebutuhan tidak terbatas sedangkan sumber daya terbatas, apakah solusinya hanya cukup secara ekonomi? Jika keinginan manusia yang hampir tak terbatas dan sumber daya yang langka, tentunya tidak bisa memenuhi semua yang diinginkan oleh masyarakat (Khan, 1995: $3-8)$.

Keinginan (want) dalam konsep kapitalis ditentukan oleh konsep utilitas, sedangkan dalam perspektif Islam ditentukan oleh konsep maslahah yang mengandung tujuan menggapai kesejahteraan manusia (maslahah al-'ibad). Oleh karena itu, dalam Islam seluruh barang dan jasa yang memiliki maslahah (human welfare) akan dikatakan sebagai kebutuhan manusia. Teori ekonomi konvensional menjelaskan, bahwa utilitas adalah merupakan barang dan jasa yang digunakan untuk memuaskan keinginan manusia (human want). Kepuasan adalah bersifat subyektif, karena setiap individu harus menentukan kepuasan menurut kriteria sendiri. Setiap kegiatan ekonomi untuk memperoleh atau menghasilkan sesuatu dimotivasi oleh utilitas. Jika sesuatu dapat memuaskan kebutuhan, seseorang akan bersedia untuk melakukan upaya untuk memproduksi, membeli atau mengkonsumsi hal itu. 
Maslahah menurut Shatibi, adalah kekayaan yang berupa barang atau jasa yang mempengaruhi unsur-unsur dasar dan tujuan dari kehidupan manusia di dunia. Unsusr-unsur itu adalah hifdz an-nafs (menjaga jiwa), din (menjaga agama), 'aql (menjaga akal), nasl (menjaga keturunan), mal (menjaga harta) dan hifdz al-biah (menjaga lingkungan) (al-Ghazali, tt: 109). Semua barang atau jasa yang memiliki kekuatan untuk mempromosikan lima elemen yang memiliki maslahah bagi manusia, maka barang atau jasa itu berarti dibutuhkan. Namun demikian, semua kebutuhan tidak sama penting. Dalam konsep maslahah terdapat tiga tingkat kebutuhan (Rahman, 1995):

1. Keinginan yang sangat penting bagi manusia, apabila tidak terpenuhi maka kepentingan dasarnya menjadi terganggu seperti makanan (QS. Thaha: 54), pakaian (QS. An-Nahl: 18) dan tempat tinggal (QS. Asy-Syuara': 128129). Keinginan ini disebut kebutuhan pokok atau dharuriyyat.

2. Kebutuhan pokok yang dapat membuat lebih berkualitas, maka disebut kebutuhan tepat guna atau hajiyyat. Hal itu dapat dicontohkan misalnya rumah yang dapat meningkatkan efisiensi kerja, makanan yang penuh dengan gizi dan lain-lain.

3. Kebutuhan yang tidak termasuk pokok dan tepat guna, tetapi mendatangkan kemudahan disebut kebutuhan kenyamanan atau tahsiniyyat. Kenyamanan atau kesenangan dibolehkan dalam Islam, asalakan tidak mengarah pada israf dan tabzir (QS. Al-A'raf: 31).

\section{Pengertian Consumer Equilibrium}

Dalam studi ekonomi konvensional, tidak bisa dilupakan pemikir Adam Smith dalam membicarakan Consumer Equilibrium. Smith telah mengkaji meskipun masih dalam konsep bayang-bayang dalam konteks division of labor. Menurut Smith: "The general industry of the society never can exceed what the capital of the society employ." Hal ini disebabkan: "Every individual is continually exerting himself to find out the most advantegous employment for whatever capital he can command." Dalam alinea berikutnya, Smith mengatakan: "But the annual revenue of every society is always equal to the exchangeable value of the whole annual produce of its industry, or rather is precisely the same thing with that exchangeable value." 
Dalam Collins Dictionary of Economics, equilibrium dijelaskan sebagai a state of balance with no tendency to change. Sedangkan definisi equilibrium menurut kamus Microsoft Bookshelf (2000), yaitu:

1. A condition in which all acting influences are canceled by others, resulting in a stable, balanced, or unchanging system;

2. Mental or emotional balance; poise;

3. Physics. The state of a body or physical system at rest or in unaccelerated motion in which the resultant of all forces acting on it is zero and the sum of all torques about any axis is zero;

4. Chemistry. The state of a chemical reaction in which its forward and reverse reactions occur at equal rates so that the concentration of the reactants and products does not change with time.

Kata equilibrium sebenarnya diadopsi dari bahasa latin "aequilībrium" yang berawalan aequi yang berkonotasi equi, dan lībra yang bermakna seimbang (balance), stabil, tidak bergerak, dan atau tidak berubah. Sedangkan menurut Collins Dictionary of Economics, equilibrium dipahami sebagai a state of balance with no tendency to change. Dalam bahasa Indonesia, equilibrium biasanya diterjemahkan sebagai keseimbangan atau kesetimbangan dan dalam bahasa Arab dikenal dengan tawazzun. Konsep keseimbangan (equilibrium), menurut ekonomika matematis, menunjuk kepada suatu titik potong (atau titik singgung) dari pertemuan dua countervailing forces yang bergerak berlawanan, misalnya, antara kurva permintaan vis-à-vis kurva penawaran, antara kurva indiferen vis$\grave{a}$-vis garis anggaran, antara kurva biaya marginal vis-à-vis garis penerimaan marginal, dan lain-lain. Titik potong atau singgung dua kurva tersebut seperti sudah menjadi sebuah magical point, yang mendikte dua countervailing forces tersebut untuk berkompromi sampai kepada outcome, yang dinamakan equilibrium point tertentu.

Adapun konsumen adalah pihak yang memakai barang-barang dan jasajasa konsumsi. Perilaku konsumen dapat di bagi menjadi 3 tahapan (Pyndick and Rubinfield, 2002: 62) : a) Preferensi Konsumen, ini adalah suatu langkah awal yang menjelaskan alasan bagaimana seseorang memilih suatu barang tertentu daripada jenis barang yang lain; b) Garis Anggaran, di sini konsumen akan mempertimbangkan faktor harga dan akan memutuskan sesuai dengan 
pendapatan yang dimilikinya. Penggabungan preferensi konsumen dengan garis anggaran akan menentukan apa yang akan dilakukan oleh konsumen tersebut; c) Pilihan-pilihan konsumen. Setelah mengetahui preferensi konsumen dan pendapatan yang dimiliki, konsumen memilih kombinasi barang-barang yang dapat memaksimalkan kebutuhan mereka.

Dalam hal alasan konsumen memilih suatu barang, dikenal tiga prinsip berikut (Karim, 2007: 64-65):

1. Kelengkapan (completeness)

Prinsip ini mengatakan bahwa setiap individu selalu dapat menentukan keadaan yang di sukainya di mana individu dihadapkan diantara dua keadaan. Sebagai contoh misalnya bila konsumen dihadapkan pada dua produk A dan B. Maka pilihan yang terjadi adalah A lebih di sukai daripada B, B lebih di sukai daripada A, A dan B sama-sama disukai atau A dan B sama-sama tidak di sukai. Preferensi ini mengabaikan faktor biaya untuk mendapatkannya.

2. Transitivitas (transitivy)

Prinsip ini menerangkan konsistensi konsumen dalam memutuskan atau menentukan alternatif dalam pilihan beberapa produk. Contoh, seorang konsumen mengatakan bahwa barang A lebih disukai daripada barang $\mathrm{B}$, Barang B lebih disukai daripada barang $\mathrm{C}$, maka tentu saja konsumen akan mengatakan bahwa barang A lebih di sukai daripada barang $\mathrm{C}$.

3. Kesinambungan (continuity)

Prinsip ini menerangkan bahwa apabila seorang konsumen mengatakan barang A lebih di sukai daripada barang B, maka setiap keadaan yang mendekati barang A lebih di sukai daripada barang B. Hal ini menunjukkan kekonsistensi konsumen dalam memilih suatu barang yang nanti akan dikonsumsinya.

4. Lebih banyak lebih baik (the more is the better)

Prinsip ini menjelaskan bahwa apabila seorang konsumen mengonsumsi lebih banyak barang maka kepuasan konsumen tersebut akan meningkat. Hal ini dapat dijelaskan melalui kurva indifference (indifference curve) yang semakin meningkat akan memberikan kepuasan yang lebih baik. Sehingga konsumen akan menambah terus konsumsinya demi mencapai 
kepuasan sebesar-besarnya meskipun keterbatasan anggaran (budget constraint) akan selalu membatasi peningkatan indifference curve.

\section{Consumer Equilibrium Perspektif Islam (Surat al-Furqan Ayat 67)}

Menggunakan pendekatan unity approuch yang digagas Anas Zarqa', nampak cukup relevan untuk memahami surat al-Furqan ayat 67 perspektif ekonomi. Dalam kajian Ulumul Qur'an, ayat ini termasuk golongan ayat-ayat makkiyah. Secara etimologis, al-Furqan berasal dari bahasa Arab berarti pembeda yang diambil dari bagian awal surat ini. Kata al-Furqan di sini dimaksudkan sebagai kitab al-Qur'an itu sendiri. Dinamai demikian, karena al-Qur'an adalah pembeda antara yang hak dengan yang batil, antara yang benar dan yang salah. Pokokpoko isi surat ini adalah membicarakan tentang keimanan, hukum-hukum, kisahkisah dan topik tentang kejadian alamiah sebagai bukti keesaan Allah SWT.

Setelah ayat-ayat sebelumnya membicarakan tentang hubungan Allah dengan makhluk serta bagaimana menjadi hamba yang ideal, kemudian digambarkan sifat manusia terhadap harta serta etika yang seharusnya dipegang oleh seorang muslim. Ayat ini juga menjadi indikasi bahwa tidak ada larangan bagi seorang muslim untuk memiliki kekayaan. Seseorang hendaknya mampu mengendalikan kekayaan bukan kekayaan yang mengendalikan manusia. Secara lengkap surat al-Furqan ayat 67 berbuni:

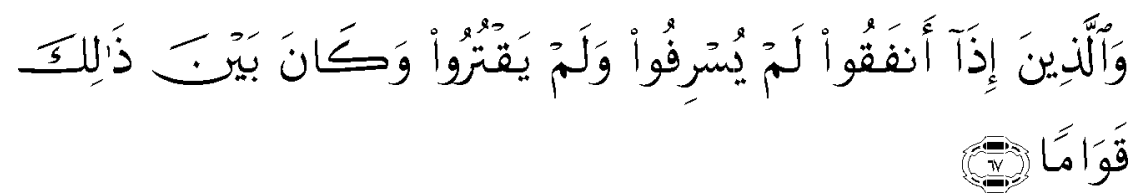

Dan orang-orang yang apabila membelanjakan (harta), mereka tidak berlebihan, dan tidak (pula) kikir, dan adalah (pembelanjaan itu) di tengah-tengah antara yang demikian (QS. Al-Furqan: 67).

Dari ayat di atas terdapat kata kunci penting untuk dijadikan landasan dalam membangun teori consumer equilibrium:

\section{Infaq}

Kata infaq merupakan bentuk kata benda dari أنفق - ينفق - إنفاقا, secara etimologis 
bermakna membelanjakan (Munawir, 2002: 1449). Secara terminologis, menurut ath-Thabathabai, kata infaq berarti mengeluarkan harta dan membelanjakan untuk memenuhi kebutuhan dirinya maupun orang lain (Ath-Thabathabai, tt: 239).

Berbeda dengan yang sering kita pahami dengan istilah infaq yang selalu dikaitkan dengan sejenis sumbangan atau donasi, istilah infaq dalam al-Qur'an masih sangat umum. Membelanjakan berarti untuk kebaikan, donasi, atau sesuatu yang bersifat untuk diri sendiri, atau bahkan keinginan dan kebutuhan yang bersifat konsumtif, semua masuk dalam istilah infaq. Dalam al-Qur'an, pengertian infaq disebutkan beragam, yaitu:

a. Membelanjakan harta

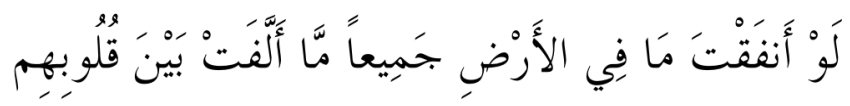

Walaupun kamu membelanjakan semua yang berada di bumi, niscaya kamu tidak dapat mempersatukan hati mereka. (QS. Al-Anfal : 63)

b. Memberi nafkah

Kata infaq ini juga berlaku ketika seorang suami membiayai belanja keluarga atau rumah tangganya. Dan istilah baku dalam bahasa Indonesia sering disebut dengan nafkah. Kata nafkah tidak lain adalah bentukan dari kata infaq. Dan hal ini juga disebutkan di dalam al-Quran :

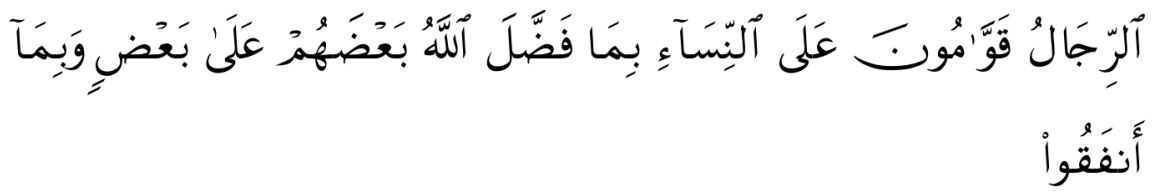

Kaum laki-laki itu adalah pemimpin bagi kaum wanita, oleh karena Allah telah melebihkan sebahagian mereka atas sebahagian yang lain, dan karena mereka telah menafkahkan sebagian dari harta mereka. (QS. An-Nisa': 34)

c. Mengeluarkan Zakat

Dan kata infaq di dalam al-Quran kadang juga dipakai untuk mengeluarkan harta (zakat) atas hasil kerja dan hasil bumi (panen).

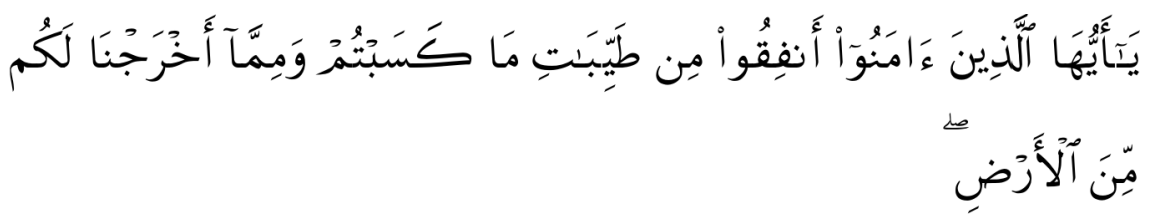


Hai orang-orang yang beriman, keluarkanlah zakat sebagian dari hasil usahamu yang baik-baik dan sebagian dari apa yang Kami keluarkan dari bumi untuk kaтu. (QS. Al-Baqarah : 267).

Dari informasi al-Qur'an di atas, dapat di simpulkan, istilah infaq itu sangat luas cakupannya, bukan hanya dalam masalah zakat atau sedekah, tetapi termasuk juga membelanjakan harta, memberi nafkah bahkan juga mendanai suatu hal, baik bersifat ibadah atau pun bukan ibadah. Termasuk yang halal atau yang haram, asalkan membutuhkan dana dan dikeluarkan dana itu, semua termasuk dalam istilah infaq. Jadi orang yang beli minuman keras yang haram hukumnya bisa disebut mengifaqkan uangnya. Orang yang membayar pelacur untuk berzina, juga bisa disebut menginfaqkan uangnya. Demikian juga orang yang menyuap atau menyogok pejabat juga bisa disebut menginfaqkan uangnya.

\section{Israf}

Kata infaq merupakan bentuk kata benda dari asrafa-yusrifu yang berarti alkhuruj 'an al-had (keluar dari batas). Dalam kaitannya dengan infaq, israf diartikan sebagai sikap melampui dari yang seharusnya dalam menggunakan harta (Ath-Thabathabai, tt: 239). Kata israf dalam al-Qur'an disebut sebanyak 23 kali dengan konteks yang berbeda-beda seperti tindakan berlebihan berkait dengan makanan dan minuman, berlebihan terhadap diri sendiri, bersedekah, berperang dan kekuasaan. Salah satu contoh ayat yang terkait dengan konsumsi:

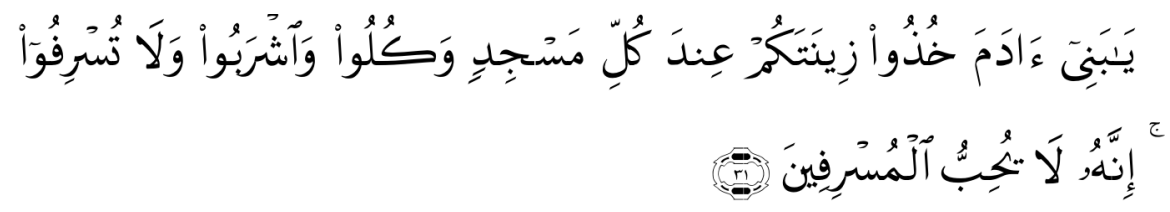

Hai anak Adam, pakailah pakaianmu yang indah di setiap (memasuki) masjid, makan dan minumlah, dan janganlah berlebih-lebihanm, sesungguhnya Allah tidak menyukai orang-orang yang berlebih-lebihan (QS. Al-A'raf, 31).

Menurut Ibnu Manzur, israf adalah melampau jbatas dalam setiap tindakan manusia, dapat berupa tindakan melampau kesederhanaan dalam hal konsumsi dari apa yang dihalalkan oleh Allah, dan membelanjakan bukan untuk ketaatan pada Allah baik dalam kuantitas kecil maupun besar dan membelanjakan bukan pada haknya (Ibnu Manzur, 148-149). Secara lebih operasional indikator- 
indikator israf dapat dijelaskan dengan beberapa petunjuk Hadis yang meliputi: a) mengkosumsi segala sesuatu yang diinginkan; b)Mengkonsumsi lebih dari apa yang dibutuhkan; c)mengkonsumsi lebih dari sepertiga penghasilan.

\section{Qatr}

Kata qatr ada bentuk kata benda dara qatara-yaqturu bermakna terlalu hemat dalam membelanjakan harta (Ath-Thabathabai, tt: 239). Kata ini adalah lawan dari kata israf yang juga dapat mengandung maksud memberi kurang dari apa yang dapat diberikan sesuai dengan keadaan pemberi dan penerima (Shihab, 2002: 533). Kata ini juga disepadanakan dengan kata bukhl atau bakhil dalam bahasa Indonesia. Secara lebih luas kedua kata ini bisa berarti menahan dari memperoleh atau mengeluarkan dari apa yang sewajarnya dan mencukupi. Beberapa indikator qathr (kikir) dan bukhl (bakhil ) adalah:

a. Menyembunyikan harta yang telah diberikan Allah

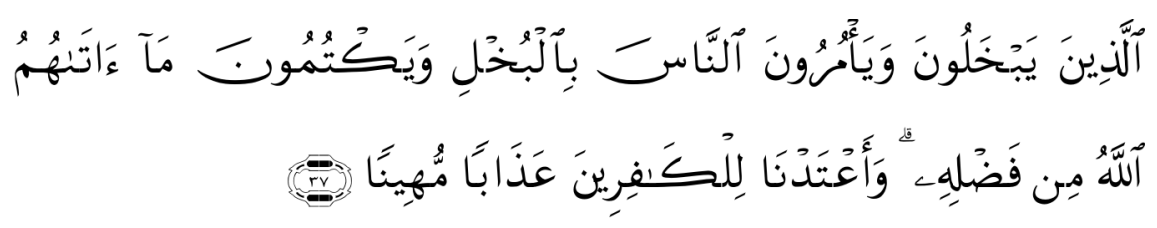

(yaitu) orang-orang yang kikir, dan menyuruh orang lain berbuat kikir, dan menyembunyikan karunia Allah yang Telah diberikan-Nya kepada mereka. dan kami telah menyediakan untuk orang-orang kafir siksa yang menghinakan (QS. AnNisa: 37).

b. Menahan harta yang selayaknya untuk dinafkahkan

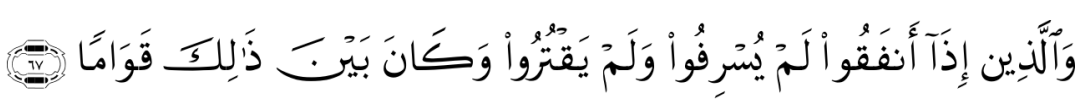

Dan orang-orang yang apabila membelanjakan (harta), mereka tidak berlebihan, dan tidak (pula) kikir, dan adalah (pembelanjaan itu) di tengah-tengah antara yang demikian (QS. Al-Furqan: 67)

c. Niat berinfak atau bersodakoh kemudian mengurungkan karena takut

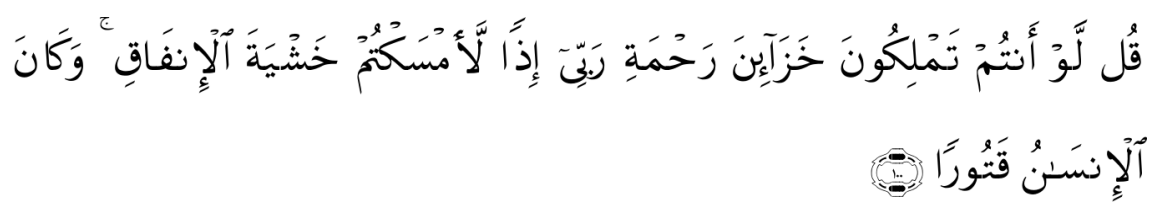


Katakanlah: "Kalau seandainya kamu menguasai perbendaharaan-perbendaharaan rahmat Tuhanku, niscaya perbendaharaan itu kamu tahan, Karena takut membelanjakannya". dan adalah manusia itu sangat kikir (QS. Al-Isra': 100)

d. Konsumsi kebutuhan dan keinginan diri dan keluarga jauh dari sepertiga. Hal itu dinyatakan dalam Hadits:

“...lalu aku sedekahkan sepertiganya, aku dan keluargaku makan sepertiganya, dan sepertiganya lagi aku investasikan (HR. Muslim).

\section{Qawam}

Kata ini dalam tarkib ayat merupakan tanshish dara kalimat "apabila mereka menafkahkan hartanya tidak berlebihan dan tidak pula kikir". Maksud dari kata itu adalah larangan sikap melampaui batas (ifrath wa tafrith), yaitu berlebihan dan kikir dan sikap ini disebut tawassuth (pertengahan) atau 'adl (adil) ((AthThabathabai, tt: 239). Pengertian qawam menurut al-Qurtubi telah dijelaskan oleh al-Qur'an sendiri dalam surat al-Isra' ayat 29:

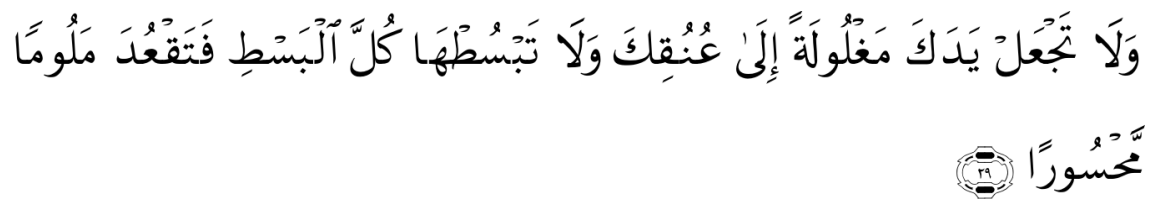

Dan janganlah kamu jadikan tanganтu terbelenggu pada lehermu dan janganlah kamu terlalu mengulurkannyaKarena itu kamu menjadi tercela dan menyesal (QS. Al-Isra: 29).

Melalui pesan tawassuth ini, Allah dan Rasulnya memberikan petunjuk agar seorang muslim hendaknya memlihara hartanya, tidak memboroskan sehingga habis, tetapi pada saat yang sama tidak dibolehkan menahannya sehingga mengorbankan kepentingan pribadi, keluarga, keluarga atau orang lain yang membutuhkan (Shihab, 2002: 533). Memelihara harta sehingga berkelanjutan adalah kewajiban agama karena hal itu termasuk dari salah satu unsur al-maqashid asySyariah al-Khamsah (al-Ghazali, tt: 109, Asy-Syatibi, tt: 2-3). Menurut Quraish Shihab, moderasi ini berlaku dalam situasi normal, sedangkan dalam situasi yang mendesak maka menjadi tidak berlaku. Sahabat Abu bakar dan Usman pernah menafkahkan setengah dari hartanya dalam rangka persiapan perang jihad menegakkan agama Allah. Jihad adalah memang dituntut untuk mengerahkan segenap kemampuan yang diniliki. Sedangkan menurut al-Qurthubi, Rasulullah 
tidak mempermasalahkan infak sahabat Abu bakar dan Usman samapi setengah bahkan keseluruhan dari yang dimiliki karena hal itu mencerminkan sikap moderat dibandingkan dengan kesabaran mereka dalam beragama (Al-Qurthubi, tt: 49).

Qawam menjadi kata kunci dalam tulisan ini untuk membangun teori tentang consumer equilibrium (keseimbangan konsumen) dalam ekonomi Islam sebagai telah jamak dikenal dalam ekonomi konvensional. Sebagaimana telah dijelaskan tentang alasan konsumen memilih suatu barang, maka dalam Islam harus dilakukan modifikasi dan penambahan yaitu :

a. Barang yang digunakan berinfak harus dalam kategori halal dan thayib. Dalam Islam konsumen dibatasi oleh aturan-aturan syariat, ada beberapa barang yang di haramkan sehingga tidak bisa di konsumsi. Karenanya konsumen hanya boleh mengonsumsi barang-barang halal baik proses maupun barangnya. Barang-barang yang thayib juga harus di masukkan, sebab belum tentu barang yang halal itu thayib. Contoh, mengonsumsi rokok. Manfaat yang di dapatkan lebih kecil ketimbang kerugian yang di terima. Ketentuan didasarkan pada surat al-Maidah ayat 4:

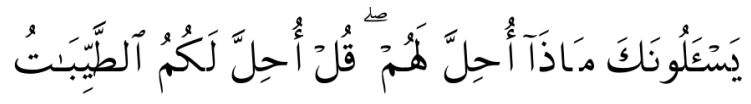

Mereka menanyakan kepadamu: "Apakah yang dihalalkan bagi mereka?”. Katakanlah: "Dihalalkan bagimu yang baik-baik".

b. Konsumen harus membelanjakan hartanya sesuai dengan kebutuhan dan kemampuan yang di miliki. sebagaimana di jelaskan dalam surat athThalaq (65) ayat 67 dan al-Baqarah 195 dan Isra': 29:

c. Membelanjakan harta tidak hanya untuk keperluan dunia semata, melainkan juga turut membelanjakan harta di jalan Allah SWT dan di niatkan untuk mendapatkan ridha dari-Nya sebagaimana dijelaskan dalam surat al-Isra' ayat 26 dan surat al-Furqan ayat 67 .

d. Konsumen muslim akan mempunyai tingkat konsumsi yang lebih kecil di bandingkan dengan konsumen non-muslim. Hal ini di karenakan konsumen muslim hanya diperbolehkan mengonsumsi barang yang halal dan thayyib saja serta adanya variabel zakat sebagaimana dinyatakan dalam surat al-Baqarah ayat 173: "Sesungguhnya Allah hanya mengharamkan 
bagimu bangkai, darah, daging babi, dan binatang yang (ketika di sembelih) di sebut (nama) selain Allah. Tetapi barang siapa dalam keadaan terpaksa sedang ia tidak menginginkan dan tidak melampaui batas, maka tidak ada dosa baginya. Sesungguhnya Allah Maha Pengampun lagi Maha Penyayang“. Allah juga menyatakan dalam surat al-Maidah ayat 93: "Tidak ada dosa bagi orang-orang yang beriman dan mengerjakan amalan yang saleh karena memakan makanan yang telah mereka makan dahulu, apabila mereka bertakwa serta beriman dan mengerjakan amalan-amalan yang saleh, kemudian mereka tetap bertakwa dan beriman, kemudian mereka (tetap juga) bertakwa dan berbuat kebajikan. Dan Allah menyukai orang-orang yang berbuat kebajikan".

e. Seorang konsumen muslim tidak menumpuk atau menimbun kekayaan melalui tabungan saja, tetapi harus melakukan investasi yang dapat mengembangkan atau memacu sirkulasi uang dalam rangka memacu dan meningkatkan pertumbuhan ekonomi. Karena tabungan yang tidak di sirkulasikan akan terkena pengurangan oleh zakat. Sebagaimana dijelaskan dalam surat at-Taubah ayat 34: "Dan orang-orang yang menyimpan emas dan perak, dan tidak menafkahkannya di jalan Allah, maka beritahukanlah kepada mereka, (bahwa mereka akan mendapat) siksaan yang pedih."

f. Konsumen muslim harus mempunyai prinsip lebih banyak tidak selalu lebih baik (the more isn't always better). Konsumen harus menyadari bahwa barang yang sebenarnya halal dan thayib sekalipun, apabila di konsumsi dalam jumlah yang besar selain mubazir, tentu akan mendatangkan kerugian bukannya kepuasan. contoh, daging sapi adalah barang yang halal dan thayib, namun daging sapi dapat mendatangkan kerugian berupa penyakit kolestrol apabila di konsumsi secara berlebih-lebihan. Sebagaimana di jelaskan dalam surat al- An'am ayat 141: "Dan Janganlah kamu berlebih-lebihan. Sesungguhnya Allah tidak menyukai orang-orang yang berlebih-lebihan."

\section{Modifikasi Model Budget line dan Kurva Indeferensi}

Dalam pembahasan terdahulu sudah dijelaskan, bahwa dalam konsep keseimbangan (equilibrium) konsumen yang teori dalam ekonomi konvensional juga 
mendapat keselarasan dalam al-Qur'an terutama surat al-Furqan ayat 67. Dalam perspektif ekonomi Islam, keseimbangan yang direpresentasikan dengan Budget line dan Kurva Indeferensi perlu dilakukan beberapa modifikasi sesuai prinsipprinsip al-Qur'an.

Perilaku konsumen dalam ekonomi konvensional dikatakan equilibriumi, apabila seseorang dapat memaksimalkan kepuasan (satisfaction) berdasarkan income dan kekayaan yang tersedia. Perilaku konsumen muslim dikatakan equilibrium apabila dapat memaksimalkan kebahagiaan di dunia dan akhirat dengan memanfaatkan incame dan kekayaan untuk meraih falah. Keseimbangan konsumen muslim menurut Kahf dapat ditulis rumus (Kahf, tt: 23):

$$
\begin{array}{ll} 
& \mathrm{w}+\mathrm{y}=\mathrm{s}+\mathrm{b}+\mathrm{c} \\
\mathrm{w} & =\text { Wealth } \\
\mathrm{y} & =\text { Income } \\
\mathrm{S} & =\text { Seving } \\
\mathrm{b} & =\text { benevolent } \\
\mathrm{c} & =\text { consumption }
\end{array}
$$

Islam memeberikan jalan tengah antara dua cara hidup yang ekstrim, yaitu batas atas dan batas bawah. Berkonsumsi secara moderat diharapkan tidak mengurangi sirkulasi-sirkulasi kekayaan dengan cara menimbun dan juga tidak melemahkan kekuatan ekonomi masyarakat akibat pemborosan (Rahman, 1985). Dalam kehidupan rumah tangga dapat dijelaskan, bahwa prinsip Islam ini adalah menyeimbangkan antara pendapatan dan pengeluaran. Dalam konteks ini ukurannya menjadi relatif karena setiap individu memiliki kebutuhan dan penghasilan yang berbeda. Inilah menurut Afzalur Rahman yang disebut Golden Mean dengan merujuk al-Furqan ayat 67.

Ayat-ayat al-Quran tersebut telah menggambarkan prinsip jalan tengah pengeluaran yang jika dijalankan sepenuhnya dapat menghapuskan kerusakankerusakan dalam ekonomi modern. Setiap orang baik kaya maupun miskin dianjurkan untuk mengeluarkan harta sesuai dengan kemampuannya. Orang kaya dapat mempertahankan standar hidupnya secara layak (baik dalam kebutuhan dan kesenangan). Pengeluaran untuk tiap kebutuhan tentu berbeda berdasarkan tanggung jawab ekonomi masing-masing. Pengeluaran disyaratkan tidak kikir 
dan tidak boros berdasarkan pendapatan para konsumen (Rahman, 1985). Menurut sebuah riwayat, Rasulullah saw pernah bersabda (Ibnu Katsir, tt: 639):

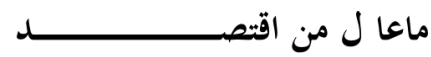

Kehidupan yang wajar (moderat) adalah sebagian dari kebahagiaan dari kehidupan ekonomi.

Untuk memahami batas-batas perilaku konsumen, maka penulis akan meminjam teori batas (nad zariyah al-hudud) yang digagas oleh M. Syahrur (Syahrur, 1994: 449). Dengan teori ini, seorang muslim tidak boleh melampau batas atas atau maksimal (al-hadd al-a'la) dan batas bawah atau minimal (al-hadd al-adna). Adapaun batasan maksimal tersebut dapat dari empat kata kunci utama yaitu israf, tabdzir, dan taraf atau batar. Empat kata kunci tersebut sejauh ini baru dapat dipahami secara kualitatif. Namun setidaknya dengan melihat indikatorindikator dapat membantu memahaminya bagaimana berkonsumsi perspektif Islam. Adapun melampaui batas minimal dalam berkonsumsi dapat dipahami dengan dua kata kunci, yaitu kikir (qathr) dan bakhil (bukhl)

Membelanjakan dan memanfaatkan kekayaan untuk memenuhi kebutuhan sehari-hari, di samping tidak boleh melampaui batas atas (al-hadd al-a 'la) juga tidak diperkenankan melampaui batas bawah (al-hadd al-adna). Kikir (qathr) bermakna serba kurang atau sempit dalam penghidupan, rizki atau nafkah. Sedangkan bakhil (bukhl) adalah menahan dari memperoleh atau mengeluarkan dari apa yang sewajarnya dan mencukupi.

Gambar (1) menunjukkan kurva budget line di bawah kurva indeferen menggambarkan perilaku konsumen yang tidak seimbang (uneqilibrium) karena mengkonsumsi di atas kemampuannya yang disebut israf. Perlu ditekankan kembali, garis diagonal (budget line/garis anggaran) sesuai prinsip-prinsip syariah tidak hanya tergantung pada penghasilan (income), tetapi juga pertimbangan maslahah. 


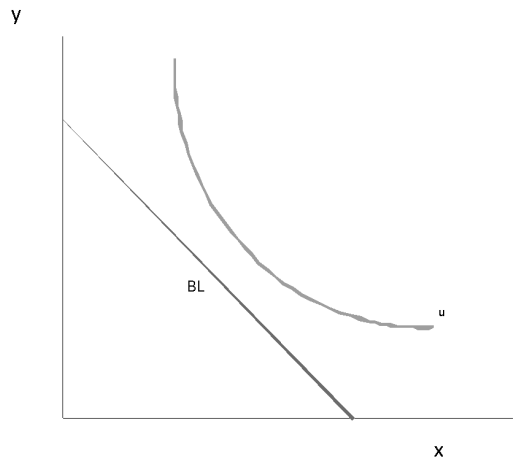

Gambar (2) menunjukkan kurva budget line tepat bersinggungan dengan kurva indeferen menggambarkan perilaku konsumen yang seimbang (eqilibrium) karena mengkonsumsi sesuai kemampuannya yang disebut qawam.

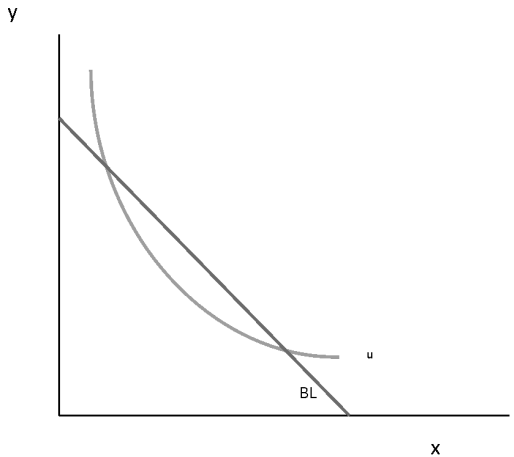

Gambar (3) menunjukkan kurva budget line di atas kurva indeferen menggambarkan perilaku konsumen yang tidak seimbang (uneqilibrium) karena mengkonsumsi di bawah kemampuannya yang disebut qatr. 


\section{Kesimpulan}

Konsep consumer equilibrium dalam ekonomi konvensional yang digambarkan dengan budget line dan kurva indeferen, dapat digunakan untuk menggambarkan maksud surat al-Furqan ayat 67. Dalam metode yang dikembangkan oleh Anas Zarqa', antara teori ekonomi dan wahyu dapat saling memperkuat. Namun demikian, karena terdapat prinsip-prinsip dasar yang berbeda seperti konsep tentang kebutuhan dan pertimbangan maslahah, maka budget line dan kurva indeferen tidak secara otomatis dapat menjelaskan maksud suatu ayat yang mengandung muatan ekonomi.

Meminjam konsep budget line dan kurva indeferen untuk menjelaskan surat al-Furqan ayat 67, maka dapat digambarkan 1) Apabila budget line di bawah kurva indeferen, maka hal itu menggambarkan perilaku konsumen kategori israf. 2) Apabila budget line di atas kurva indeferen, maka hal itu menggambarkan perilaku konsumen kategori qatr. 3) Apabila budget line tepat bersinggungan dengan kurva indeferen, maka hal itu menggambarkan perilaku konsumen yang ideal yaitu qawam (equilibirium).

\section{Daftar Pustaka}

A.W. Munawir. 2002. Kamus Al-Munawwir Arab Indonesia, Yogyakarta: Pustaka progresif.

Agil, Syed Omar Syed. 1992. "Consumer Behavior" in an Islamic Framework in Reading in Microeconomics: An Islamic Prespective (Malaysia: Darul Ehsan

al-Ghazali, Abu Hamid. tt. Ihya Ulumiddin. Beirut: Dar an-Nahdah. Jilid 2,

Al-Ghazali, Muhammad bin Muhammad Abu Hamid. 1993. Al-Mustashfa $f i$ Ushûl al-Figh. Beirut: Dar al-Kutub al-Ilmiyah.

Al-Qurthubi, Abi Abdullah Muhammad Ibnu Ahmad al-Anshari. Tt. al-Jami' li Ahkam al-Qur'an. Beirut: Dar al-kutub al-'Ilmiyah. Jilid 13-14.

Asy-Syatibi. tt. al-Muwāfaqāt. Ttp: Dar al-Fikri. juz II

Ath-Thabathabai, Muhammad Husain. tt. Al-Mizan fi Tafsir al-Qur'an, Beirut: Muassasah al-A'la lil Mathbu'at. Jilid 15 
Bank Indonesia, 1998. Tentang Perubahan Undang-Undang No. 7 tahun 1992

-------. 2002. Cetak Biru Pengembangan Perbankan Syariah Nasional Periode 2002-2011. Jakarta: BI.

-------. 2010. Statistik Perbankan Syariah Juni 2009. Jakarta: Direktorat Perbankan Syariah.

BNI Syariah, Prospek Bank Syariah Pasca Fatwa MUI, Yogyakarta: Suara Muhammadiyah, 2005.

Boediono. 2002. Ekonomi Mikro. Yogyakarta: BPFE.

Buchory, Herry Ahmad dan Djasmin Saladin. 2006. Dasar-dasar Pemasaran Bank. Bandung: Linda Karya.

Cengiz Erol dan Radi El-Bdour, "Attitude, Behaviour and Patronage Factors of Bank Customers towards Islamic Banks", dalam International Journal of Bank Marketing, Vol. 7, No. 6, 1989.

Chapra, M. Umer \& Habib Ahmed. 2002. Corporate Governance in Islamic Financial Institution. Jeddah: Ocasional Paper IDB.

Chapra, M. Umer, The Future of Economic; An Islamic perspektif (Masa Depan Ilmu Ekonomi: Sebuah Tinjauan Islam), alih bahasa Ikhwan Abidin Basri (jakarta: Gema I nsani Press, 2001).

--------. 2001. Kata Pengantar dalam The Future of Economics: An Islamic Perspective (Masa Depan Ilmu Ekonomi: Sebuah Tinjauan Islam), alih bahasa Ikhwan Abidin Basri. Jakarta: Gema Insani Press.

Dillon, William R. 1984. Multivariate Analysis Methods and Applications. Toronto: John Wiley \& Sons Inc.

Elgari, M.A., Same Islamic Insights on the Theory of Consumer Behavior in Aspect of Islamic Economics and The Economy of Indian Muslims (Edited by F.R. Faridi), (New Delhi: Genuine Publication \& Distributors, 2002).

Fahim, Khan, M. 1995. Essays in Islamic Economic. United Kingdom: The Islamic Foundation.

Gerrard, Philip dan Cunningham, J. Barton, "Islamic Banking: a Study in Singapore, International Journal of Bank Marketing, Vol. 15 No. 6, 1997.

Hadi, Sutrisno. 1991. Statistik. Yogyakarta: Andi Offset

Ibnu Katsir. tt. Tafsir Ibnu Kasir. Suriyah: Dar al-Qalam 
Ibnu Manzur. Lisan al- 'Arab. Beirut: Dar Ash-Shadr

Kahf, Monzer. 1979. The Islamic Economy: Analytical of yhe Functioning of the Islamic Econimic System, Palinfield, In: Muslim Studiens Assosciation of USA and Canada.

--------. tt. The Demand Side of Consumer Behavior: Islam Perspective. tp. 1995. The Islamic Economy of the Functioning of the Islamic Economic System (Ekonomi Islam: Telaah Analitik terhadap Fungsi Sistem Ekonomi Islam), alih bahasa Machnun Husen. Yogyakarta: Pustaka Pelajar.

------. 1992. Theory of Consumption in an Islamic Framework in Reading in Microeconomics: An Islamic Prespective. Malaysia: Darul Ehsan.

Karim , Adiwarman A. 2007. Ekonomi Mikro Islami. Jakarta: PT Rajagrafindo Persada.

Karim, Adiwarman A. 2010. Bank Islam: Analisis Fiqih dan Keuangan. Jakarta: Rajawali Press

Kasmir, 2004. Pemasaran Bank. Jakarta: Kencana

Khan, M. Fahim. 1995. Essays in Islamic Economic. United Kingdom: The Islamic Foundation.

Kotler, Philip. 1997. Marketing Management: Analysis, Planning, Implementation, and Control. Ninth Edition. New York: Prentice-Hall.

Loudon, D. L., Della Bitta, A.J. 1995. ConsumerBehavior: Concepts and Applications. $4^{\text {th }}$ Edition. New York: McGraw-Hill.

Mas'ud, Muhammad Khalid. 1995. Filsafat Hukum Islam dan Perubahan Sosial (Islamic Legal Philosofy: A Studi of Abu Ishaq asy-Syatibi's Life and Thought). Surabaya: al-Ikhlas.

Mowen, John C. dan Michael. 2001. Perilaku Konsumen (terjemahan) Jilid 1 Edisi kelima, Erlangga.

Oliver, Richard L. "Cognitive, Affective, and Attribute Bases of the Satisfaction Respones", Journal of Consumer Research, Desember 1993.

Pusat Pengkajian dan Pengembangan Ekonomi Islam (P3EI) UII Yogyakarta dan Bank Indonesia. 2008. Ekonomi Islam, Jakarta: PT Rajagrafindo Persada.

Pyndick, Robert S. and Daniel L Rubinfield. 2002. Microeconomics. (New York: Prentice Hall. 
Rahardjo, M. Dawam. 1998. Islam dan Transformasi Sosial-Ekonomi. Jakarta: LSAF.

Rahman, Afzalur. 1985. Economic Doctrines of Islam, Lahore: Islamic Publication.

Reksoprayitno, Soediyono. 2007. Pengantar Ekonomi Mikro, Yogyakarta: BPFE.

Shihab, M. Quraish. 1992. Membumikan al-Qur'an: Fungsi dan Peran Wahyu dalam Kehidupan Masyarakat, Bandung: Mizan.

Shihab, M. Quraish. 2002. Tafsir al-Misbah: Pesan, Kesan dan Keserasian alQur'an, Jakarta: Lentera Hati.

Syahrur, Muhammad. 1994. al-Kit āb wa al-Qur'an: Qira'ah al-Mu'ashirah. Damaskus: al-Ahab li al-T li al-Nashr wa al-Tauz'. 